\title{
Energy Analysis in Combined Reforming of Propane
}

\author{
K. Moon and Ganesh R. Kale \\ CEPD Division, National Chemical Laboratory, Pune 411008, India \\ Correspondence should be addressed to Ganesh R. Kale; gr.kale@ncl.res.in
}

Received 30 November 2012; Revised 21 May 2013; Accepted 21 May 2013

Academic Editor: Mo Yang

Copyright (C) 2013 K. Moon and G. R. Kale. This is an open access article distributed under the Creative Commons Attribution License, which permits unrestricted use, distribution, and reproduction in any medium, provided the original work is properly cited.

Combined (steam and $\mathrm{CO}_{2}$ ) reforming is one of the methods to produce syngas for different applications. An energy requirement analysis of steam reforming to dry reforming with intermediate steps of steam reduction and equivalent $\mathrm{CO}_{2}$ addition to the feed fuel for syngas generation has been done to identify condition for optimum process operation. Thermodynamic equilibrium data for combined reforming was generated for temperature range of $400-1000^{\circ} \mathrm{C}$ at 1 bar pressure and combined oxidant $\left(\mathrm{CO}_{2}+\mathrm{H}_{2} \mathrm{O}\right)$ stream to propane (fuel) ratio of 3, 6, and 9 by employing the Gibbs free energy minimization algorithm of HSC Chemistry software 5.1. Total energy requirement including preheating and reaction enthalpy calculations were done using the equilibrium product composition. Carbon and methane formation was significantly reduced in combined reforming than pure dry reforming, while the energy requirements were lower than pure steam reforming. Temperatures of minimum energy requirement were found in the data analysis of combined reforming which were optimum for the process.

\section{Introduction}

Syngas $\left(\mathrm{H}_{2}+\mathrm{CO}\right)$ is an important commodity for various applications. It is used as fuel in internal combustion (IC) engines [1-5], raw material for chemical manufacture by FT synthesis to produce hydrocarbons [6-9], for synthesis of liquefied petroleum gas (LPG) [10, 11], gasoline [12], alcohols [13-18], dimethyl ether [19-21], methanethiol [22], and also as a fuel for SOFC in fuel cells $[23,24]$. It has been used as raw material as fuel in gas turbines [25-27], for use in coal liquefaction [28], for use in cofiring and reburning in a coal fired boiler [29], and also to synthesize biofuels by syngas fermentation [30].

Solid oxide fuel cell (SOFC) has the unique distinction of using syngas instead of pure hydrogen for electricity generation as it treats $\mathrm{CO}$ equivalent to hydrogen in feed [31]. Although some researchers have reported lower efficiencies with CO compared to hydrogen, the cost of pure hydrogen production can always cap these results for cheap power generation from SOFC [32-34].

Steam reforming (SR) $[35,36]$ and dry reforming (DR) [37] are well-known processes for syngas/hydrogen generation [38]. SR is preferred for hydrogen generation, and
DR is preferred for syngas generation. The total moles of syngas generated are of importance for SOFC feed from the hydrocarbon fuel, and these processes generate equivalent amount of syngas from fuels and hence are comparable [3941]. But both these processes are highly endothermic and also have their inherent drawbacks. SR requires huge energy for steam generation (as water has a huge latent heat of vaporization), while $\mathrm{DR}$ process is prone to catalyst deactivation due to coke formation [42] (coke formation in steam reforming is much less). The improvement to these processes was the addition of oxygen to make it thermoneutral (neither endothermic nor exothermic) processes. However addition of oxygen also adds nitrogen which although is inert increases the reactor volumes which increases the capital as well as operating costs. The steam to propane ratio $(\mathrm{S} / \mathrm{P})$ in steam reforming and carbon dioxide to propane ratio $\left(\mathrm{CO}_{2} / \mathrm{P}\right)$ in dry reforming are important feed parameters [43]. Both $\mathrm{H}_{2} \mathrm{O}$ and $\mathrm{CO}_{2}$ supply oxygen to the fuel, and they get reduced to $\mathrm{H}_{2}$ and $\mathrm{CO}$, respectively, which add up to the syngas moles generated from the carbon and hydrogen of the fuel. These oxidants (Oxs) can be combined in suitable ratios for reforming to lower the energy requirements and avoid carbon formation. This oxidant to propane ratio (Ox/P or OxPR) 
TABLE 1: Input feed conditions for different (OxPRs) oxidant to feed ratio.

\begin{tabular}{lccc}
\hline $\begin{array}{l}\text { Feed } \\
\text { condition }\end{array}$ & $\begin{array}{c}\text { Oxidant to propane } \\
\text { ratio (OxPR) }\end{array}$ & $\begin{array}{c}\text { Moles of } \\
\mathrm{H}_{2} \mathrm{O}\end{array}$ & $\begin{array}{c}\text { Moles of } \\
\mathrm{CO}_{2}\end{array}$ \\
\hline A10 & 3 & 3 & 0 \\
$\mathrm{~A} 11$ & 3 & 2 & 1 \\
$\mathrm{~A} 12$ & 3 & 1 & 2 \\
$\mathrm{~A} 13$ & 3 & 0 & 3 \\
$\mathrm{~B} 10$ & 6 & 6 & 0 \\
$\mathrm{~B} 11$ & 6 & 5 & 1 \\
$\mathrm{~B} 12$ & 6 & 4 & 2 \\
$\mathrm{~B} 13$ & 6 & 3 & 3 \\
$\mathrm{~B} 14$ & 6 & 2 & 4 \\
$\mathrm{~B} 15$ & 6 & 1 & 5 \\
$\mathrm{~B} 16$ & 6 & 0 & 6 \\
$\mathrm{C} 10$ & 9 & 9 & 0 \\
$\mathrm{C} 11$ & 9 & 8 & 1 \\
$\mathrm{C} 12$ & 9 & 7 & 2 \\
$\mathrm{C} 13$ & 9 & 6 & 3 \\
$\mathrm{C} 14$ & 9 & 5 & 4 \\
$\mathrm{C} 15$ & 9 & 4 & 5 \\
$\mathrm{C} 16$ & 9 & 3 & 6 \\
$\mathrm{C} 17$ & 9 & 1 & 7 \\
$\mathrm{C} 18$ & 9 & 9 \\
$\mathrm{C} 19$ & 9 & & \\
\hline & 9 & 2 & 5 \\
\hline
\end{tabular}

is a very important parameter in combined reforming. This paper intends to study the energy requirements in combined reforming to find optimum temperature of operation. The study is planned in steps such as to start by pure steam $\left(\mathrm{H}_{2} \mathrm{O}\right)$ reforming and gradually add $\mathrm{CO}_{2}$ moles and reduce equivalent $\mathrm{H}_{2} \mathrm{O}$ from the feed, and study the process energy trends requirements. Such systematic studies have not been reported in the literature yet (according to the authors). This paper intends to study these conditions and arrive at the optimum points of operation which will immensely benefit the existing fuel processor technology. Propane is a major constituent of liquefied petroleum gas (LPG) which is widely available and hence is chosen for this study [44].

\section{Methodology}

Reforming reactions are generally equilibrium-limited. The thermodynamic equilibrium data points for the study were generated by HSC Chemistry software ver. 5.1 [45]. This software uses the popular Gibbs free minimization technique to find the equilibrium composition of the system [46-49]. These data points can also be generated by other commercial software like HYSIS, Design II, Aspen Plus. Fluent or also by programming the algorithm in C++, JAVA, or MATLAB. The particular advantage with HSC chemistry is it works using species rather than chemical equations and hence can work in conditions where exact number and nature of chemical reaction equations and intermediate species are not known.
The amount of input species and desired output species are to be defined along with temperature and pressure conditions and the software calculates the equilibrium compositions which can be used in the reaction equation module of HSC chemistry to calculate the process enthalpy [50-54]. 1 mole of propane is used as fuel for all conditions in this study while OxPR chosen for this study was 3, 6, and 9 (starting from pure steam reforming and ending to pure dry reforming for OxPR 3, 6, and 9). The intermediate points are combined $\left(\mathrm{H}_{2} \mathrm{O}+\mathrm{CO}_{2}\right) /$ Propane ratio (OxPR) of 3, 6 and 9 in respective cases. At each ratio condition, the $\mathrm{H}_{2} \mathrm{O}$ in feed was gradually decreased (by 1 mole) with equivalent $\mathrm{CO}_{2}$ addition and equilibrium compositions, and reaction energy was calculated. The feed conditions are shown in detail in Table 1 . The calculations were done within $400-1000^{\circ} \mathrm{C}$ at 1 bar pressure using propane as fuel. The preheating energies of steam, $\mathrm{CO}_{2}$, and propane were calculated by standard manual techniques using specific heat $(\mathrm{Cp})$ data [55].

\section{Results and Discussions}

The energy requirements based on equilibrium product compositions for the steam reforming to dry reforming in gradual steps for the oxidant to propane ratio 3-9 were calculated and analysed. The energy requirements included only the preheating and reaction enthalpies assuming that the hot gases can be utilized directly by the SOFC.

3.1. Syngas Production. Syngas $\left(\mathrm{H}_{2}+\mathrm{CO}\right)$ is a major product in all reforming processes. The syngas generation potential for a fuel depends on its component hydrogen and carbon moles. Propane $\left(\mathrm{C}_{3} \mathrm{H}_{8}\right)$ consists of 3 carbon and 4 hydrogen moles, so the maximum syngas moles that can be obtained by steam reforming and dry reforming processes (individually) are 10 as shown by the following reaction equations:

$$
\begin{aligned}
& \mathrm{C}_{3} \mathrm{H}_{8}+3 \mathrm{H}_{2} \mathrm{O}=3 \mathrm{CO}+7 \mathrm{H}_{2} \\
& \mathrm{C}_{3} \mathrm{H}_{8}+3 \mathrm{CO}_{2}=6 \mathrm{CO}+4 \mathrm{H}_{2}
\end{aligned}
$$

Increase in the moles of $\mathrm{H}_{2} \mathrm{O}$ (in SR) and $\mathrm{CO}_{2}$ (in DR) does not affect the syngas potential of the fuel although it affects the equilibrium syngas moles. The syngas moles produced in combined reforming of reforming for oxidant to propane ratio OxPR 6 (i.e., various conditions ranging from $\mathrm{S} /$ Propane $=6$ to $\mathrm{CO}_{2} /$ Propane $\left.=6\right)$ are shown in Figure 1 in temperature ranging from $400-1000^{\circ} \mathrm{C}$. It was observed that the syngas moles increased with increase in temperature from 400 to $1000^{\circ} \mathrm{C}$ at a constant 1 bar pressure. For example, the syngas moles increased from 1.3045 to 9.9988 moles in pure steam reforming (B10), while the syngas moles increased from 0.4689 to 9.9996 moles in case of pure dry reforming (B16), while for equimolar moles of $\mathrm{CO}_{2}$ and $\mathrm{H}_{2} \mathrm{O}$ (B13), the syngas moles increased from 0.8142 to 9.9990 moles. At a constant temperature, the syngas moles decreased with increase in the moles of $\mathrm{CO}_{2}$ for temperature up to $800^{\circ} \mathrm{C}$, and they become nearly constant to 10.00 moles at higher temperatures. For example, at $600^{\circ} \mathrm{C}$, syngas moles decreased from 6.4164 to 3.9080 moles. The minimum syngas moles 


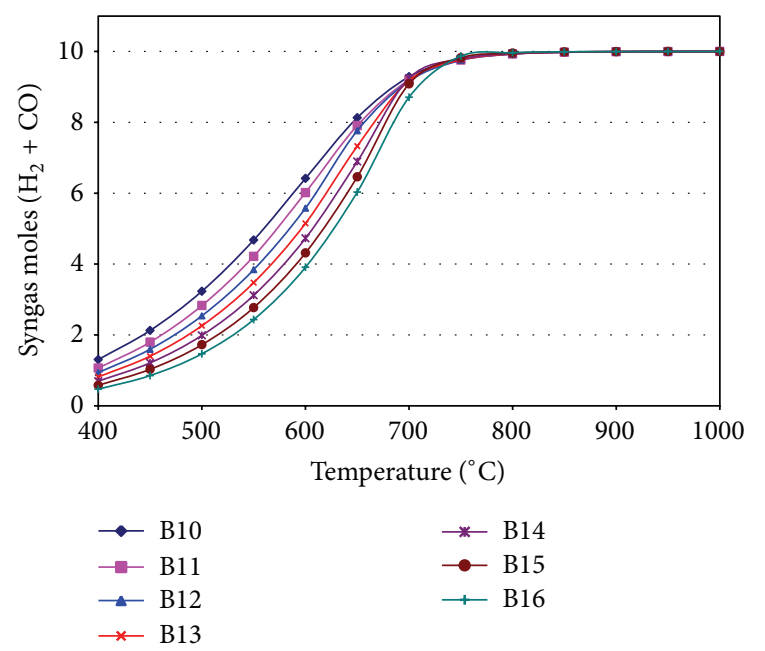

FIGURE 1: Syngas moles in CR of propane.

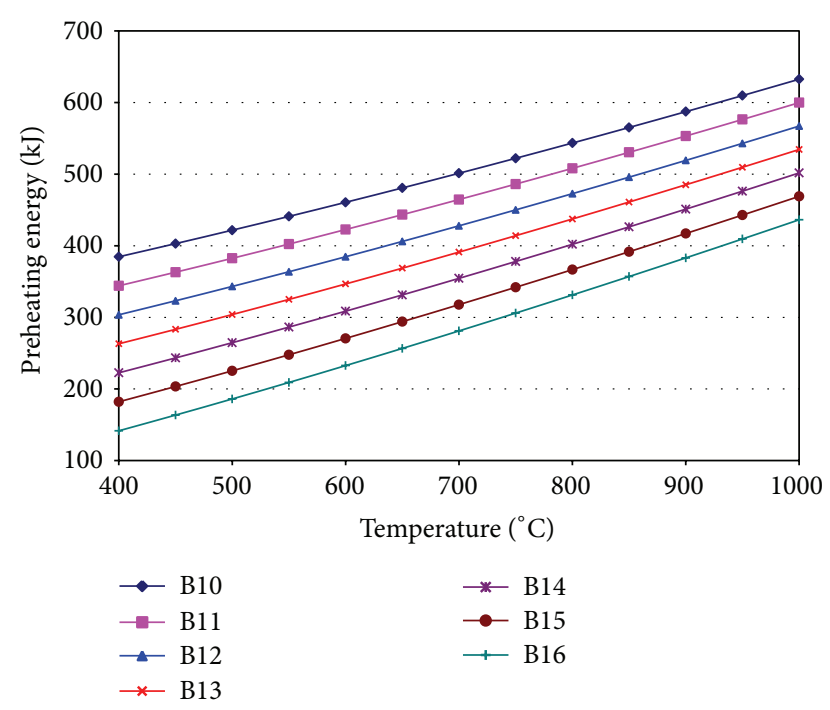

FIgure 2: Preheating Energy in CR of propane.

were produced at $400^{\circ} \mathrm{C}$ for case $\mathrm{B} 16$ ( 0.4689 moles $)$ while the maximum syngas moles of $\sim 10.00$ moles were obtained for all cases above $800^{\circ} \mathrm{C}$. Same trends was observed for OxPR $=3$ and 9. In case of $\mathrm{OxPR}=3$, the minimum syngas moles were found to be 0.4638 for case $\mathrm{A} 13$ at $400^{\circ} \mathrm{C}$ and the maximum syngas moles of $\sim 9.85$ moles were obtained for all cases at $1000^{\circ} \mathrm{C}$, while in $\mathrm{OxPR}=9$, the minimum syngas moles were found to be 0.4856 for case $\mathrm{C} 19$ at $400^{\circ} \mathrm{C}$ and the maximum syngas moles of $\sim 10.00$ were obtained for all cases at $750^{\circ} \mathrm{C}$.

3.2. Preheating Energy. Preheating energy is the energy which is required to heat the reactants from the room temperature (generally from $25^{\circ} \mathrm{C}$ ) to the reaction temperature.

Figure 2 shows the variation of preheating energy within the temperature range of $400-1000^{\circ} \mathrm{C}$ at 1 bar pressure for reactants (propane, steam, and $\mathrm{CO}_{2}$ ) of combined reforming of propane for $\mathrm{OxPR}=6$. It was observed that the preheating energy increased with increase in temperature.

For example, in case of pure steam reforming (B10), preheating energy increased from 384.6027 to $632.5468 \mathrm{~kJ}$ for increase in temperature from 400 to $1000^{\circ} \mathrm{C}$. In case of pure dry reforming (B16), it increased from 141.5922 to $436.2769 \mathrm{~kJ}$ while for equimolar moles of $\mathrm{CO}_{2}$ and $\mathrm{H}_{2} \mathrm{O}$ (B13), it increased from 263.0974 to $534.4119 \mathrm{~kJ}$. At constant temperature, the preheating energy decreased with increase in the moles of $\mathrm{CO}_{2}$. (It is a valid observation and hence kept as it is.) For example, at $800^{\circ} \mathrm{C}$, the preheating energy decreased from 543.4448 to $331.2756 \mathrm{~kJ}$. The minimum preheating energy was found to be $141.5922 \mathrm{~kJ}$ at $400^{\circ} \mathrm{C}$ for case $\mathrm{B} 16$ whereas the maximum preheating energy was found to be $632.5468 \mathrm{~kJ}$ at $1000^{\circ} \mathrm{C}$ for case B10. Same trend was observed for OxPRs $=3$ and 9. In case of $\mathrm{OxPR}=3$, the minimum preheating energy was found to be $91.2433 \mathrm{~kJ}$ at $400^{\circ} \mathrm{C}$ for case $\mathrm{A} 13$, whereas maximum preheating energy was $387.827 \mathrm{~kJ}$ at $1000^{\circ} \mathrm{C}$ for case A10 (dry reforming condition). While in OxPR $=9$, the minimum preheating energy was found to be $191.9410 \mathrm{~kJ}$ at $400^{\circ} \mathrm{C}$ for case $\mathrm{C} 19$ and the maximum preheating energy was found to be $877.2667 \mathrm{~kJ}$ at $1000^{\circ} \mathrm{C}$ for $\mathrm{C} 10$.

3.3. Reaction Enthalpy. Figure 3 shows the variation of reaction enthalpy within temperature range of $400-1000^{\circ} \mathrm{C}$ at 1 bar pressure for $\mathrm{OxPR}=6$. It was observed that the reaction enthalpy increased with increase in temperature.

For example, it increased from 19.332 to $521.401 \mathrm{~kJ}$ in case of pure steam reforming (B10), it increased from -42.558 to $672.38 \mathrm{~kJ}$ in case of pure dry reforming (B16), and for equimolar moles of $\mathrm{CO}_{2}$ and $\mathrm{H}_{2} \mathrm{O}$ (B13), it increased from $-16.721 \mathrm{~kJ}$ to $598.876 \mathrm{~kJ}$ with increase in temperature from 400 to $1000^{\circ} \mathrm{C}$. At lower temperature range (i.e., below $650^{\circ} \mathrm{C}$ ), the reaction enthalpy decreased with increase in $\mathrm{CO}_{2}$ moles at constant temperature while reverse trend was observed for higher temperature range. For example, at a constant temperature of $500^{\circ} \mathrm{C}$, the reaction enthalpy decreased from $114.625 \mathrm{~kJ}$ to 19.254 , while at $850^{\circ} \mathrm{C}$ the reaction enthalpy increased from 514.53 to $670.696 \mathrm{~kJ}$. The reaction enthalpies were nearly same in between the temperatures from $650^{\circ} \mathrm{C}$ to $700^{\circ} \mathrm{C}$ for all considered cases (i.e., from B10 to B16). The minimum enthalpy was found to be $-42.558 \mathrm{~kJ}$ at $400^{\circ} \mathrm{C}$ for case B16, whereas maximum enthalpy was found to be $672.38 \mathrm{~kJ}$ at $1000^{\circ} \mathrm{C}$ in B16. Same trend was observed for OxPR $=3$ and 9 . In case of $\mathrm{OxPR}=3$, the minimum enthalpy was found to be $-40.87 \mathrm{~kJ}$ at $400^{\circ} \mathrm{C}$ for case $\mathrm{A} 13$, while the maximum enthalpy was $624.497 \mathrm{~kJ}$ at $1000^{\circ} \mathrm{C}$ for case A13. At $\mathrm{OxPR}=9$, the minimum enthalpy was found to be $-41.975 \mathrm{~kJ}$ at $400^{\circ} \mathrm{C}$ for case $\mathrm{C} 19$ and the maximum enthalpy was found to be $694.467 \mathrm{~kJ}$ at $1000^{\circ} \mathrm{C}$ for $\mathrm{C} 19$ case.

3.4. Total Energy per Mole of Syngas. Process energy plays an important role in chemical process development. Both steam and dry reforming are endothermic processes, and their energy requirements are high. The energy required for production of syngas from one mole of propane was calculated as the summation of energy required for preheating the feed and energy required for reaction (reaction enthalpy). It was 
assumed that the product gases existing at high temperatures can be directly fed to the SOFC, and hence, there is no need to cool down the product gases. Using the data of syngas produced and energy required at different temperatures, this data of energy requirement per mole of syngas produced in each case for $\mathrm{OxPR}=3,6$, and 9 was generated. The data for each OxPR case was found to be of the same nature.

Figure 4 shows the variation of total energy per mole of syngas within temperature range from 400 to $1000^{\circ} \mathrm{C}$ at 1 bar pressure for $\mathrm{OxPR}=6$. It was observed that the total energy per mole of syngas first decreased to a certain temperature near about $700^{\circ} \mathrm{C}$ and then increased slightly with increase in temperature. The total energy per mole of syngas decreased from $211.2054 \mathrm{~kJ}\left(400^{\circ} \mathrm{C}\right)$ to $97.6488 \mathrm{~kJ}$ $\left(700^{\circ} \mathrm{C}\right)$ and then increased to $110.8701 \mathrm{~kJ}$ at $1000^{\circ} \mathrm{C}$ for pure dry reforming condition (B16). The total energy per mole of syngas decreased from $309.6471 \mathrm{~kJ}\left(400^{\circ} \mathrm{C}\right)$ to $103.9103 \mathrm{~kJ}$ $\left(700^{\circ} \mathrm{C}\right)$ and then increased to $115.4086 \mathrm{~kJ}$ at $1000^{\circ} \mathrm{C}$ for pure steam reforming condition (B10), while for equimolar condition (B13), the total energy per mole of syngas decreased from $302.5994 \mathrm{~kJ}\left(400^{\circ} \mathrm{C}\right)$ to $100.6861 \mathrm{~kJ}\left(700^{\circ} \mathrm{C}\right)$ and then increased to $113.3401 \mathrm{~kJ}$ at $1000^{\circ} \mathrm{C}$. At lower temperature, the total energy per mole of syngas initially increased and then decreased with an increase in number of moles of $\mathrm{CO}_{2}$ in the oxidant (simultaneously decrease in the moles of $\mathrm{H}_{2} \mathrm{O}$ ) from $\mathrm{B} 10$ to B16. For example at $400^{\circ} \mathrm{C}$, the total energy per mole of syngas increased from $309.6471 \mathrm{~kJ}$ (B10) to $328.2746 \mathrm{~kJ}$ (B11) and then decreased to $211.2054 \mathrm{~kJ}$ (B16). The minimum total energy per mole of syngas was found to be $97.6488 \mathrm{~kJ}$ at $700^{\circ} \mathrm{C}$ for case of B16, while the maximum total energy per mole of syngas observed was $328.2746 \mathrm{~kJ}$ at $400^{\circ} \mathrm{C}$ for case of B11.

3.5. Optimum Temperature. The optimum temperature of process operation for each case was found by using the data of the energy per mole of syngas curve in the earlier section. The data of the curves was fitted to a MS Excel, and the minimum of the curves was found for their respective optimum temperature (the optimum is for the combined reformer and not the SOFC part, and single stage reforming without WGS is considered in this study). This temperature, at which a minimum of total energy required per mole of syngas produced was observed, was considered to be the best operating temperature for generating syngas at that particular feed condition. Figure 5 shows the optimum temperatures for all reforming cases plotted against minimum energy required to produce 1 mole of syngas in combined reforming of propane. The optimum temperature showed an irregular pattern for increase in $\mathrm{CO}_{2}$ moles for each case of OxPR. A decrease in the minimum total energy per mole of syngas was observed for an increase in the number of moles of $\mathrm{CO}_{2}$ in the oxidant feed, which implies that the least energy was required in the case of pure dry reforming. The variation of this optimum temperature was high for OxPR $=3$ (715$\left.780^{\circ} \mathrm{C}\right)$, but it was low for $\mathrm{OxPR}=6\left(717-719^{\circ} \mathrm{C}\right)$ and was again slightly higher for $\mathrm{OxPR}=9\left(678-680^{\circ} \mathrm{C}\right)$. Table 2 shows the temperatures at which minimum total energy per mole of syngas is obtained at pressure $1 \mathrm{bar}$.

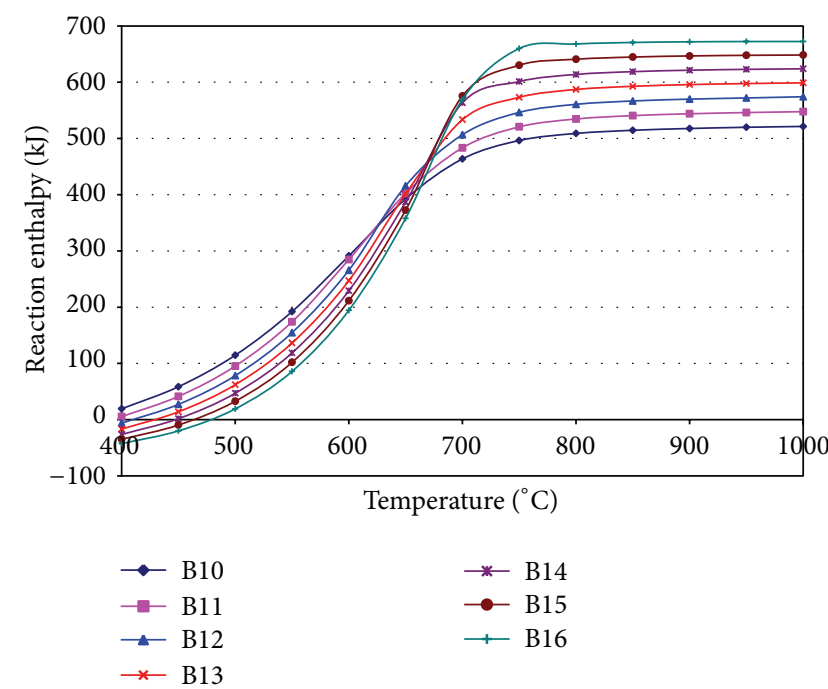

FIGURE 3: Reaction enthalpy in CR of propane.

3.6. Minimum Total Energy per Mole of Syngas at Optimum Temperature. Figure 6 shows the variation of minimum total energy per mole syngas for all $\mathrm{OxPR}$ cases $=3,6$, and 9. From the previous discussion of total energy per mole of syngas, it can be observed that the total energy required per mole of syngas reached a minimum value at a certain temperature. With an increase in number of moles of $\mathrm{CO}_{2}$ in the oxidant feed, it was observed that a decrease in the minimum total energy per mole of syngas which implies that least energy is required in the case of dry reforming in all cases as steam generation is highly energy consuming. For example, at 1 bar pressure, in pure steam reforming condition of $\mathrm{OxPR}=3$, the minimum total energy per mole of syngas is $88.9909 \mathrm{~kJ}$ which reduces to $86.8565 \mathrm{~kJ}$ at pure dry reforming. Similarly for $\mathrm{OxPR}=6$, the minimum total energy per mole of syngas is $103.7013 \mathrm{~kJ}$ which reduces to $96.7485 \mathrm{~kJ}$, and for OxPR $=9$, the minimum total energy per mole of syngas is $120.832 \mathrm{~kJ}$ which reduces to $105.7698 \mathrm{~kJ}$ from steam to dry reforming.

3.7. Syngas Moles at Optimum Temperature. The moles of syngas generated at the optimum temperature conditions for all the OxPRs (3-9) were analyzed and plotted in Figure 7. It was observed that the moles of syngas produced decreased from 8.6826 to 6.4853 (for OxPR = 3), but for $\mathrm{OxPR}=6$, the syngas yield decreased slightly from 9.5362 to 9.3922 and then increased to 9.659 , while for $\mathrm{OxPR}=9$, it slightly decreased from 9.5934 to 9.3930 and then increased to 9.6776 . The maximum syngas yield at optimum temperatures was obtained for dry reforming condition for OxPRs 6 and 9, while for $\mathrm{OxPR}=3$ the maximum syngas moles were generated at optimum temperature for steam reforming. The variation in syngas moles was high for $\mathrm{OxPR}=3$ while it was low for OxPRs $=6$ and 9. The maximum amount of syngas (9.6776 moles) was produced in dry reforming condition of $\mathrm{OxPR}=9$ at the optimum temperature of $678^{\circ} \mathrm{C}$ from 1 mole propane at the energy expense of $105.7698 \mathrm{~kJ} / \mathrm{mole}$ syngas. 
TABle 2: Optimum temperatures in combined reforming of propane.

\begin{tabular}{lcccccccccc}
\hline No. of moles of $\mathrm{CO}_{2}$ & 0 & 1 & 2 & 3 & 4 & 5 & 6 & 7 & 8 & 9 \\
\hline Temperatures at $\mathrm{OxPR}=3$ & 780 & 774 & 760 & 715 & - & - & - & - & - & - \\
Temperatures at $\mathrm{OxPR}=6$ & 719 & 720 & 720 & 716 & 709 & 707 & 717 & - & - & - \\
Temperatures at $\mathrm{OxPR}=9$ & 680 & 684 & 686 & 687 & 685 & 685 & 676 & 671 & 670 & 678 \\
\hline
\end{tabular}

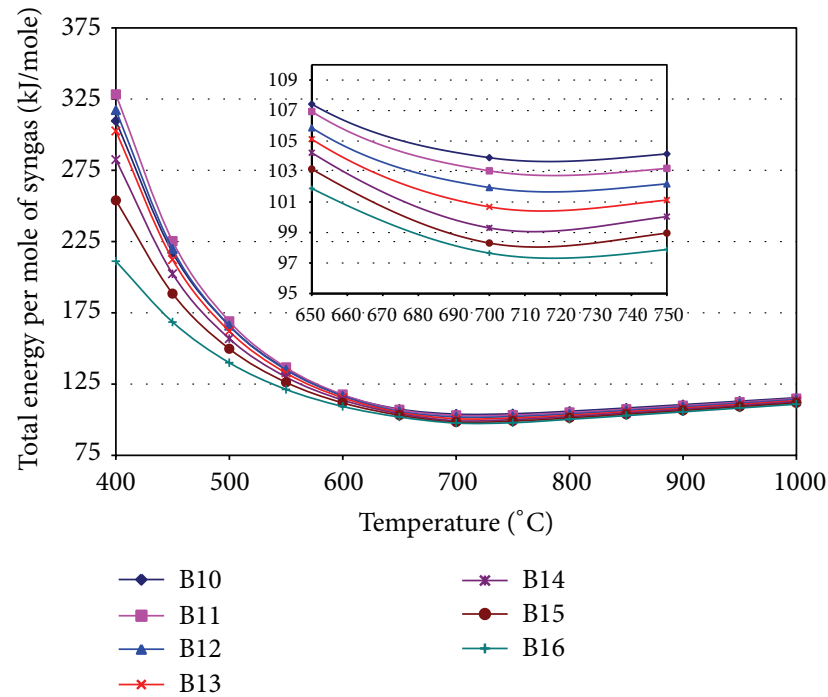

FIGURE 4: Total energy per mole of syngas in CR of propane.

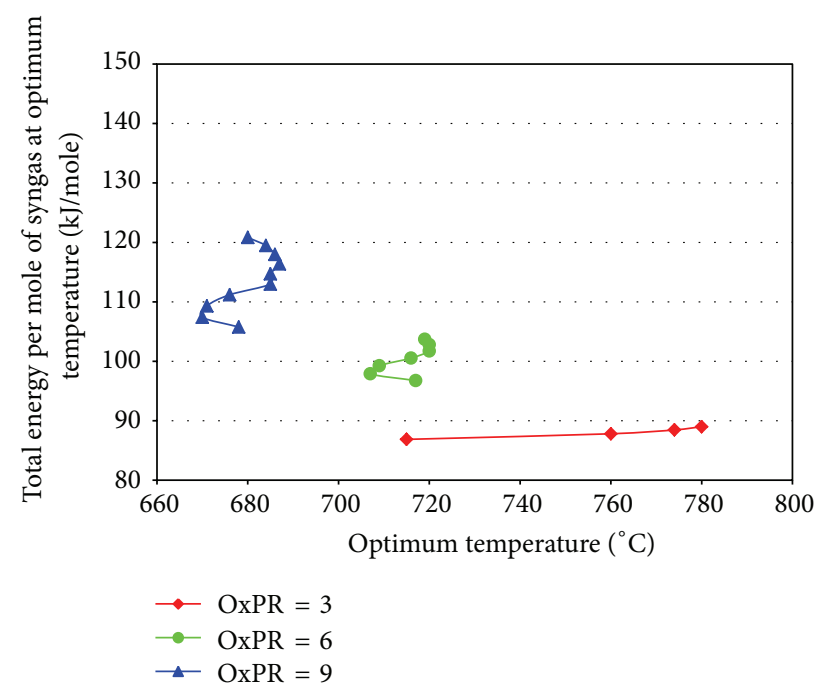

Figure 5: Optimum temperatures in CR of propane.

3.8. Syngas Ratio at Optimum Temperature. Figure 8 shows the syngas ratio at the optimum temperature with increase in moles of $\mathrm{CO}_{2}$. It was observed that as the number of moles of $\mathrm{CO}_{2}$ in the oxidant feed increased, the syngas ratio decreased. For example, in case of $\mathrm{OxPR}=6$, the syngas ratio decreased from 3.7394 (B10) to 0.4696 (B16). At a constant feed input of $\mathrm{CO}_{2}$, as the OxPr increased from 3 to 9 , the syngas ratio increased. For example, in case of pure steam

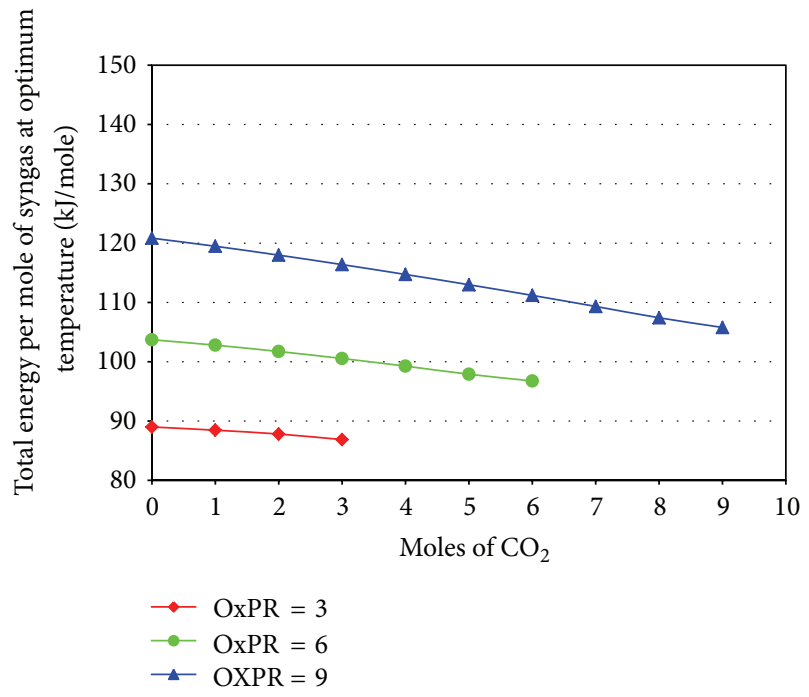

FIgURE 6: Minimum total energy per mole syngas at optimum temperature in CR of propane.

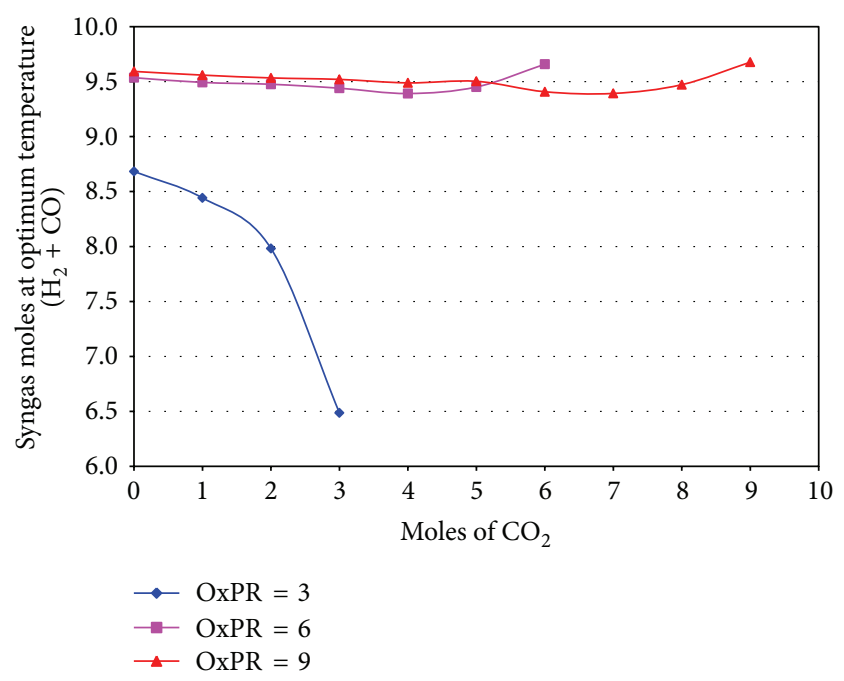

FIGURE 7: Syngas moles at optimum temperature in CR of propane.

reforming condition, the syngas ratio increased from 2.5413 $(\mathrm{OxPR}=3)$ to $5.5884(\mathrm{OxPR}=9)$. The maximum syngas ratio was found to be 5.5884 at pure steam reforming condition of $\mathrm{OxPR}=9$, while the minimum syngas ratio was found to be 0.3919 at pure dry reforming condition of $\mathrm{OxPR}=9$.

\subsection{Byproduct Formation at Optimum Temperature}

3.9.1. Carbon Formation. Carbon is an undesired component of reforming processes as it deactivates the catalyst and 


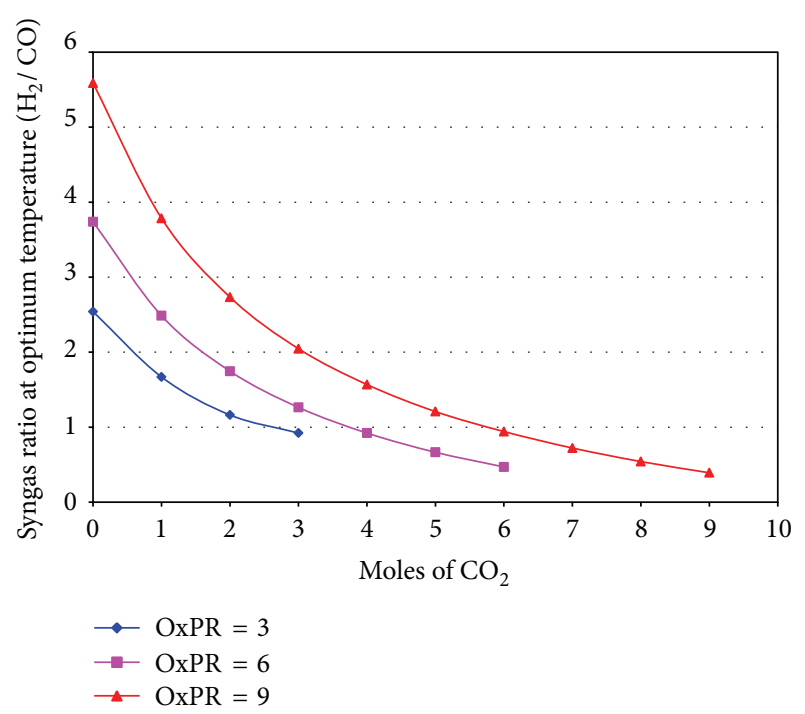

FIGURE 8: Syngas ratio at optimum temperature in CR of propane.

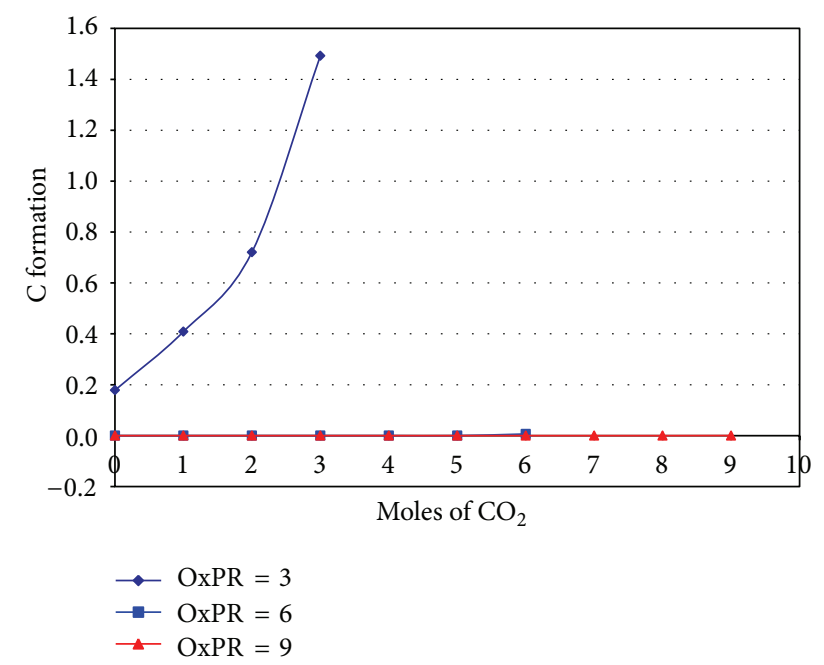

FIGURE 9: Carbon formation at optimum temperature in CR of Propane.

causes pressure drop in the reactors but is mostly produced in reforming processes. Conditions for negligible carbon formation are of importance for process operation. Figure 9 shows the variation of carbon formation at the optimum temperature with increase in moles of $\mathrm{CO}_{2}$ in combined reforming of propane. Zero carbon formation was observed for OxPRs $=6$ and 9, while the carbon formation for $\mathrm{OxPR}=3$ increased from 0.1786 to 1.4925 moles with increase in moles of feed $\mathrm{CO}_{2}$. The carbon formation decreased with increase in reforming temperature.

3.9.2. Methane Formation at Optimum Temperature. Methane is also a byproduct of reforming process. Methane formation is sometimes undesirable due to the loss of hydrogen and carbon moles. Figure 10 shows the variation in methane formation at optimum temperature with increase in moles of

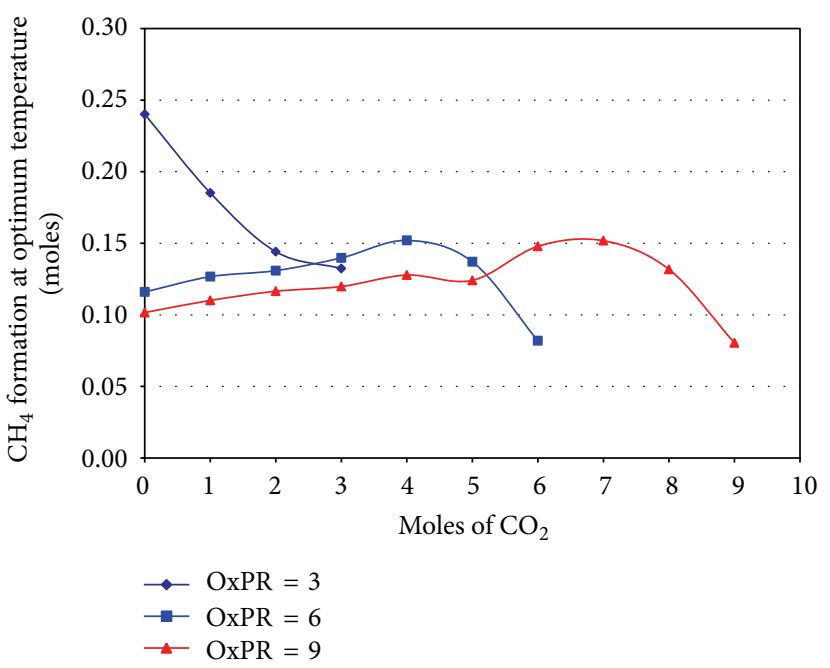

FIGURE 10: Methane formation at optimum temperature in CR of Propane.

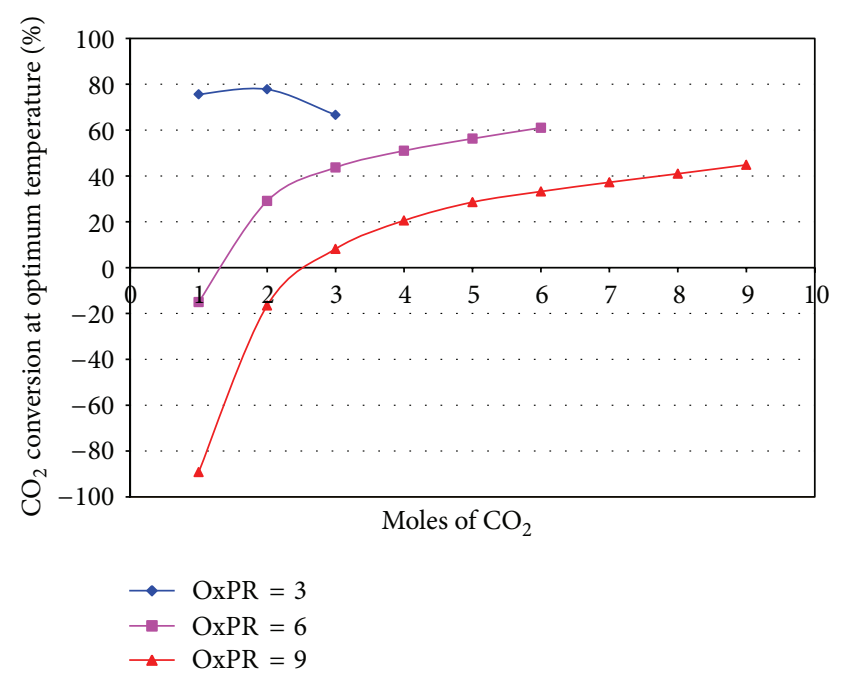

FIGURE 11: $\mathrm{CO}_{2}$ conversion at optimum temperature in $\mathrm{CR}$ of Propane.

feed $\mathrm{CO}_{2}$. It was observed that methane formation decreased for OxPR $=3$ while for OxPR = 6 it first increased and then decreased with increase in $\mathrm{CO}_{2}$ moles, and it showed a mixed trend for $\mathrm{OxPR}=9$ as the number of moles of $\mathrm{CO}_{2}$ in the oxidant feed was increased. For example, the methane formation decreased from 0.2401 to 0.1324 moles in the case of $\mathrm{OxPR}=3$, and for $\mathrm{OxPR}=6$ it first increased from 0.116 to 0.1520 moles and then decreased to 0.0819 moles. The minimum methane formation was found to be 0.0804 moles for $\mathrm{OxPR}=9(\mathrm{C} 19)$ while the maximum methane moles were obtained (0.2401 moles) for OxPR $=3$ (A10).

Tables 3, 4, and 5 show the product composition for the temperature at which minimum total energy per mole of syngas was obtained for OxPRs $=3,6$, and 9 . 
TABLE 3: Optimum parameters in combined reforming of propane at case $\mathrm{OxPR}=3$.

\begin{tabular}{lcccc}
\hline No. of moles of $\mathrm{CO}_{2}$ & 0 & 1 & 2 & 3 \\
Temperature $\left({ }^{\circ} \mathrm{C}\right)$ & 780 & 774 & 760 & 7.2914 \\
\hline $\mathrm{H}_{2}(\mathrm{~g})$ & 6.2308 & 5.2799 & 3.6907 & 3.111 \\
$\mathrm{CO}(\mathrm{g})$ & 2.4518 & 3.1621 & 0.4204 & 3.3743 \\
$\mathrm{H}_{2} \mathrm{O}(\mathrm{g})$ & 0.2891 & 0.3498 & 0.4445 & 0.6242 \\
$\mathrm{CO}_{2}(\mathrm{~g})$ & 0.1296 & 0.2441 & 0.1441 & 1.0008 \\
$\mathrm{CH}_{4}(\mathrm{~g})$ & 0.2401 & 0.1852 & 0.7207 & 0.1324 \\
$\mathrm{C}$ & 0.1786 & 0.4087 & 7.9821 & 1.4925 \\
Syngas $\left(\mathrm{H}_{2}+\mathrm{CO}\right)$ & 8.6826 & 8.4420 & 1.1628 & 6.4853 \\
Syngas ratio $(\mathrm{H} / \mathrm{CO})$ & 2.5413 & 1.6697 & 0.1139 & 0.9220 \\
$\mathrm{H}_{2} \mathrm{O} / \mathrm{CO}$ & 0.1179 & 0.1106 & 57.96 & 0.1850 \\
$\mathrm{H}_{2} \mathrm{O}$ conversion & 90.363 & 82.51 & 77.775 \\
$\mathrm{CO}_{2}$ conversion & - & 75.59 & - \\
\hline
\end{tabular}

TABLE 4: Optimum parameters in combined reforming of propane at case $\mathrm{OxPR}=6$.

\begin{tabular}{lccccccc}
\hline No. of moles of $\mathrm{CO}_{2}$ & 0 & 1 & 2 & 3 & 4 & 5 & 707 \\
Temperature & 719 & 720 & 720 & 716 & 709 & 717 \\
\hline $\mathrm{H}_{2}(\mathrm{~g})$ & 7.5241 & 6.7701 & 6.0260 & 5.2700 & 4.5049 & 3.7755 & 3.0866 \\
$\mathrm{CO}(\mathrm{g})$ & 2.0121 & 2.7230 & 3.4505 & 4.1707 & 4.8873 & 5.6761 & 6.5724 \\
$\mathrm{H}_{2} \mathrm{O}(\mathrm{g})$ & 2.2440 & 1.9765 & 1.7123 & 1.4504 & 1.1912 & 0.9503 & 0.7495 \\
$\mathrm{CO}_{2}(\mathrm{~g})$ & 0.8720 & 1.1503 & 1.4186 & 1.6895 & 1.9608 & 2.1868 & 2.3390 \\
$\mathrm{CH}_{4}(\mathrm{~g})$ & 0.1160 & 0.1267 & 0.1309 & 0.1398 & 0.1520 & 0.1371 \\
$\mathrm{C}$ & 0 & 0 & 0 & 0 & 0 & 0.0819 \\
Syngas $\left(\mathrm{H}_{2}+\mathrm{CO}\right)$ & 9.5362 & 9.4931 & 9.4765 & 9.4407 & 9.3922 & 9.4516 & 0 \\
Syngas Ratio $\left(\mathrm{H}_{2} / \mathrm{CO}\right)$ & 3.7394 & 2.4863 & 1.7464 & 1.2636 & 0.9218 & 0.6652 & 0.4590 \\
$\mathrm{H}_{2} \mathrm{O} / \mathrm{CO}$ & 1.1153 & 0.7259 & 0.4962 & 0.3478 & 0.2437 & 0.1674 & 0.1140 \\
$\mathrm{H}_{2} \mathrm{O}$ conversion & 62.6 & 60.47 & 57.1925 & 51.653 & 40.44 & 4.97 \\
$\mathrm{CO}_{2}$ conversion & - & -15.03 & 29.07 & 43.683 & 50.98 & 56.264 \\
\hline
\end{tabular}

3.10. Feed Conversions. Propane was found to be completely converted $(100 \%)$ in all the considered cases. The feed $\mathrm{CO}_{2}$ and $\mathrm{H}_{2} \mathrm{O}$ conversions are discussed below.

\subsubsection{Carbon Dioxide Conversion at Optimum Temperature.} Figure 11 shows the variation of $\mathrm{CO}_{2}$ conversion at optimum temperatures for combined reforming of propane. From the figure, it was observed that as the number of moles of $\mathrm{CO}_{2}$ in the oxidant feed increased, the $\mathrm{CO}_{2}$ conversion first increased and then decreased for OxPR $=3$ while it increased with increase in $\mathrm{CO}_{2}$ moles or OxPRs $=6$ and 9. For example, in the case of $\mathrm{OxPR}=3$, the $\mathrm{CO}_{2}$ conversion first increased from $75.59 \%$ to $77.78 \%$ and then decreased to $66.64 \%$, while for $\mathrm{OxPR}=6$, it increased from $-15.03 \%$ to $61.01 \%$ and it increased from $-89.21 \%$ to $44.82 \%$ for OxPR $=$ 9. Considering all the cases of OxPR from 3-9, the maximum $\mathrm{CO}_{2}$ conversion was found to be $77.78 \%$ at $760^{\circ} \mathrm{C}$ for case $\mathrm{B} 12$ and the minimum $\mathrm{CO}_{2}$ conversion was found to be $-89.21 \%$ at $684^{\circ} \mathrm{C}$ for case $\mathrm{C} 11$. The negative $\mathrm{CO}_{2}$ conversion shows the net $\mathrm{CO}_{2}$ generation in the reforming system.

3.10.2. Steam Conversion at Optimum Temperature. Figure 12 shows the variation of $\mathrm{H}_{2} \mathrm{O}$ conversion at optimum temperatures for combined reforming of propane. From the figure, it was observed that as the number of feed moles of $\mathrm{CO}_{2}$ in the oxidant feed was increased, the $\mathrm{H}_{2} \mathrm{O}$ conversion decreased for all OxPRs. For example, in the case of OxPR 3, $\mathrm{H}_{2} \mathrm{O}$ conversion decreased from $90.36 \%$ to $57.96 \%$, while for OxPR $=6$, it decreased from $62.60 \%$ to $4.97 \%$, and it decreased from $48.23 \%$ to $-40.94 \%$ for $\mathrm{OxPR}=9$. Considering all the cases of OxPR 3-9, the maximum $\mathrm{H}_{2} \mathrm{O}$ conversion was found to be $90.36 \%$ at $780^{\circ} \mathrm{C}$ for case $\mathrm{B} 10$ and minimum was found to be $-40.94 \%$ at $670^{\circ} \mathrm{C}$ for case $\mathrm{C} 18$. The negative $\mathrm{H}_{2} \mathrm{O}$ conversion shows the net $\mathrm{H}_{2} \mathrm{O}$ generation in the reforming system.

\section{Conclusion}

The thermodynamic energy analysis of combined steam and dry reforming of propane with intermediate steps was studied in this paper. The optimum temperatures (optimum temperature for reformer operation is considered in this study) at which minimum total energy required to produce 1 mole syngas obtained in all cases of OxPRs $=3,6$, and 9 for combined reforming were found in each case. The combined reforming process at $\mathrm{OxPR}=3$ although gave the lowest energy requirement per mole of syngas generated, carbon formation was observed at those process conditions, and hence those conditions may not be used for fuel processor 
TABLE 5: Optimum parameters in combined reforming of propane at case OxPR $=9$.

\begin{tabular}{lcccccccccc}
\hline No. of moles of $\mathrm{CO}_{2}$ & 0 & 1 & 2 & 3 & 4 & 5 & 6 & 7 & 8 & 9 \\
Temperature $\left({ }^{\circ} \mathrm{C}\right)$ & 680 & 684 & 686 & 687 & 685 & 685 & 676 & 671 & 670 & 678 \\
\hline $\mathrm{H}_{2}$ & 8.1373 & 7.5619 & 6.9807 & 6.3950 & 5.7948 & 5.1992 & 4.5632 & 3.9387 & 3.3269 & 2.7247 \\
$\mathrm{CO}$ & 1.4561 & 1.9978 & 2.5535 & 3.1257 & 3.6942 & 4.3043 & 4.8451 & 5.4543 & 6.1458 & 6.9529 \\
$\mathrm{H}_{2} \mathrm{O}$ & 4.6594 & 4.2180 & 3.7864 & 3.3654 & 2.9497 & 2.5526 & 2.1410 & 1.7578 & 1.4094 & 1.1145 \\
$\mathrm{CO}_{2}$ & 1.4423 & 1.8921 & 2.3301 & 2.7545 & 3.1781 & 3.5716 & 4.0070 & 4.3940 & 4.7224 & 4.9663 \\
$\mathrm{CH}_{4}$ & 0.1016 & 0.1101 & 0.1165 & 0.1198 & 0.1278 & 0.1241 & 0.1479 & 0.1518 & 0.1318 & 0.0804 \\
$\mathrm{C}$ & 0 & 0 & 0 & 0 & 0 & 0 & 0 & 0 & 0 & 0 \\
Syngas $\left(\mathrm{H}_{2}+\mathrm{CO}\right)$ & 9.5934 & 9.5597 & 9.5342 & 9.5207 & 9.4890 & 9.5035 & 9.4083 & 9.3930 & 9.4727 & 9.6776 \\
Syngas ratio $(\mathrm{H} / \mathrm{CO})$ & 5.5884 & 3.7851 & 2.7338 & 2.0459 & 1.5686 & 1.2079 & 0.9418 & 0.7221 & 0.5413 & 0.3919 \\
$\mathrm{H}_{2} \mathrm{O} / \mathrm{CO}$ & 3.1999 & 2.1113 & 1.4828 & 1.0767 & 0.7985 & 0.5930 & 0.4419 & 0.3223 & 0.2293 & 0.1603 \\
$\mathrm{H}_{2} \mathrm{O}$ conversion & 48.2288 & 47.275 & 45.908 & 43.91 & 41.006 & 36.185 & 28.633 & 12.11 & -40.94 & - \\
$\mathrm{CO}_{2}$ conversion & - & -89.21 & -16.505 & 8.1833 & 20.5475 & 28.568 & 33.216 & 37.228 & 40.97 & 44.818 \\
\hline
\end{tabular}

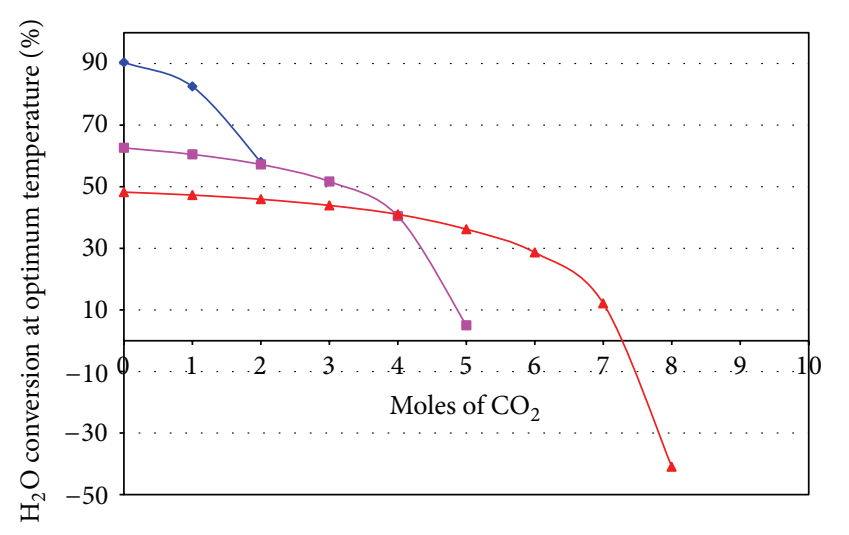

$$
\begin{aligned}
& \rightarrow \text { OxPR }=3 \\
& \rightarrow \text { OxPR }=6 \\
& \longrightarrow \text { OxPR }=9
\end{aligned}
$$

Figure 12: $\mathrm{H}_{2} \mathrm{O}$ conversion at optimum temperature in $\mathrm{CR}$ of Propane.

operation for SOFC. The minimum energy per mole of syngas produced was direct proportional to the oxidant moles used in the process while it had an inverse relation to the optimum process temperature. Dry reforming cases produced more syngas than steam reforming cases at OxPRs $=6$ and 9 but the trend was reverse at $\mathrm{OxPR}=3$. Carbon and methane were the imminent byproducts in combined reforming. Zero carbon formation was observed for OxPRs $=6$ and 9. The syngas generated at the optimum conditions had ratio between 1 and 5 and can also be used for petrochemical manufacture by the Fischer-Tropsch synthesis. At optimum conditions, the maximum moles of syngas obtained were 9.6776 for OxPR $=9$ at $678^{\circ} \mathrm{C}$, and minimum (zero) carbon formation was observed in OxPR OxPRs 6 and 9 while minimum methane formation of 0.0804 moles at $\mathrm{OxPR}=9$ was observed. The maximum $\mathrm{CO}_{2}$ conversion was observed to be $77.78 \%$ while the maximum $\mathrm{H}_{2} \mathrm{O}$ conversion was observed to be $90.36 \%$ in $\mathrm{OxPR}=3$ condition .

\section{References}

[1] M. Baratieri, P. Baggio, B. Bosio, M. Grigiante, and G. A. Longo, "The use of biomass syngas in IC engines and CCGT plants: a comparative analysis ," Applied Thermal Engineering, vol. 29, no. 16, pp. 3309-3318, 2009.

[2] C. D. Rakopoulos and C. N. Michos, "Development and validation of a multi-zone combustion model for performance and nitric oxide formation in syngas fueled spark ignition engine," Energy Conversion and Management, vol. 49, no. 10, pp. 29242938, 2008.

[3] C. D. Rakopoulos, C. N. Michos, and E. G. Giakoumis, "Availability analysis of a syngas fueled spark ignition engine using a multi-zone combustion model," Energy, vol. 33, no. 9, pp. 13781398,2008

[4] A. Shah, R. Srinivasan, S. D. Filip To, and E. P. Columbus, "Performance and emissions of a spark-ignited engine driven generator on biomass based syngas," Bioresource Technology, vol. 101, no. 12, pp. 4656-4661, 2010.

[5] D. Monarca, A. Colantoni, M. Cecchini et al., "Energy characterization and gasification of biomass derived by hazelnut cultivation: analysis of produced syngas by gas chromatography," Mathematical Problems in Engineering, vol. 2012, Article ID 102914, 9 pages, 2012.

[6] K.-W. Jun, H.-S. Roh, K.-S. Kim, J.-S. Ryu, and K.-W. Lee, "Catalytic investigation for Fischer-Tropsch synthesis from biomass derived syngas," Applied Catalysis A, vol. 259, no. 2, pp. 221-226, 2004.

[7] T. Riedel, M. Claeys, H. Schulz et al., "Comparative study of Fischer-Tropsch synthesis with $\mathrm{H}_{2} / \mathrm{CO}$ and $\mathrm{H}_{2} / \mathrm{CO}_{2}$ syngas using Fe- and Co-based catalysts," Applied Catalysis A, vol. 186, no. 1-2, pp. 201-213, 1999.

[8] A. Demirbas, "Converting biomass derived synthetic gas to fuels via Fisher-Tropsch synthesis," Energy Sources A, vol. 29, no. 16, pp. 1507-1512, 2007.

[9] A. A. Mirzaei, S. Vahid, and M. Feyzi, "Fischer-tropsch synthesis over iron manganese catalysts: effect of preparation and operating conditions on catalyst performance," Advances in Physical Chemistry, vol. 2009, Article ID 151489, 12 pages, 2009.

[10] K. Asami, Q. Zhang, X. Li, S. Asaoka, and K. Fujimoto, "Semiindirect synthesis of LPG from syngas: conversion of DME into LPG," Catalysis Today, vol. 106, no. 1-4, pp. 247-251, 2005. 
[11] Q. Ge, Y. Lian, X. Yuan, X. Li, and K. Fujimoto, "High performance $\mathrm{Cu}-\mathrm{ZnO} / \mathrm{Pd}-\beta$ catalysts for syngas to LPG," Catalysis Communications, vol. 9, no. 2, pp. 256-261, 2008.

[12] A. Martínez, S. Valencia, R. Murciano, H. S. Cerqueira, A. F. Costa, and E. F. S.-Aguiar, "Catalytic behavior of hybrid $\mathrm{Co} / \mathrm{SiO}_{2}$ (medium-pore) zeolite catalysts during the one-stage conversion of syngas to gasoline," Applied Catalysis A, vol. 346, no. 1-2, pp. 117-125, 2008.

[13] M. Inoue, T. Miyake, Y. Takegami, and T. Inui, "Direct alcohol synthesis from syngas on $\mathrm{Ru}-\mathrm{Mo}-\mathrm{Na} / \mathrm{Al}_{2} \mathrm{O}_{3}$ catalysts: effects of physical properties of alumina supports," Applied Catalysis, vol. 29, no. 2, pp. 285-294, 1987.

[14] M. Inoue, T. Miyake, S. Yonezawa, D. Medhanavyn, Y. Takegami, and T. Inui, "Direct synthesis of alcohols from syngas on Ru-Mo- $\mathrm{Na}_{2} \mathrm{O} / \mathrm{Al}_{2} \mathrm{O}_{3}$ catalysts: synergistic effect of $\mathrm{Ru}$ and Mo," Journal of Molecular Catalysis, vol. 45, no. 1, pp. 111-126, 1988.

[15] M. Xiang, D. Li, W. Li, B. Zhong, and Y. Sun, "Synthesis of higher alcohols from syngas over K/Co/ $\beta$-Mo2C catalysts," Catalysis Communications, vol. 8, no. 3, pp. 503-507, 2007.

[16] G. Lu, C.F. Zhang, Y.Q. Gang et al., "Synthesis of mixed alcohols from $\mathrm{CO}_{2}$ contained syngas on supported molybdenum sulfide catalysts," Applied Catalysis A, vol. 150, no. 2, pp. 243-252, 1997.

[17] T. Jiang, Y. Niu, and B. Zhong, "Synthesis of higher alcohols from syngas over Zn-Cr-K catalyst in supercritical fluids," Fuel Processing Technology, vol. 73, no. 3, pp. 175-183, 2001.

[18] H. Zhang, X. Yang, L. Zhou, Y. Su, and Z. Liu, "Conversion of syngas to higher alcohols over $\mathrm{Cu}-\mathrm{Fe}-\mathrm{Zr}$ catalysts induced by ethanol," Journal of Natural Gas Chemistry, vol. 18, no. 3, pp. 337-340, 2009.

[19] D. M. Brown, B. L. Bhatt, T. H. Hsiung, J. J. Lewnard, and F. J. Waller, "Novel technology for the synthesis of dimethyl ether from syngas," Catalysis Today, vol. 8, no. 3, pp. 279-304, 1991.

[20] W.-Z. Lu, L.-H. Teng, and W.-D. Xiao, "Simulation and experiment study of dimethyl ether synthesis from syngas in a fluidized-bed reactor," Chemical Engineering Science, vol. 59, no. 22-23, pp. 5455-5464, 2004.

[21] K. Asami, Q. Zhang, X. Li, S. Asaoka, and K. Fujimoto, "Semiindirect synthesis of LPG from syngas: conversion of DME into LPG," Catalysis Today, vol. 106, no. 1-4, pp. 247-251, 2005.

[22] A. Chen, Q. Wang, Q. Li, Y. Hao, W. Fang, and Y. Yang, "Direct synthesis of methanethiol from $\mathrm{H}_{2} \mathrm{~S}$-rich syngas over sulfided Mo-based catalysts," Journal of Molecular Catalysis A, vol. 283, no. 1-2, pp. 69-76, 2008.

[23] C. O. Colpan, I. Dincer, and F. Hamdullahpur, "Thermodynamic modeling of direct internal reforming solid oxide fuel cells operating with syngas," International Journal of Hydrogen Energy, vol. 32, no. 7, pp. 787-795, 2007.

[24] L. Hong, X. Yin, and Z. Gong, "A decrease in NiO-MgO phase through its solid solution equilibrium with tetragonal $\left(\mathrm{La}_{1-z}\right.$ $\left.\mathrm{Sr}_{z}\right)_{2} \quad \mathrm{Ni}_{1-y} \quad \mathrm{Mg}_{y} \quad \mathrm{O}_{4-\delta}$ : effect on catalytic partial oxidation of methane," Journal of Nanomaterials, vol. 2012, Article ID 263568, 10 pages, 2012.

[25] S. M. Walton, X. He, B. T. Zigler, and M. S. Wooldridge, "An experimental investigation of the ignition properties of hydrogen and carbon monoxide mixtures for syngas turbine applications," Proceedings of the Combustion Institute, vol. 31, pp. 3147-3154, 2007.

[26] Y. S. Kim, J. J. Lee, T. S. Kim, J. L. Sohn, and Y. J. Joo, "Performance analysis of a syngas-fed gas turbine considering the operating limitations of its components," Applied Energy, vol. 87, no. 5, pp. 1602-1611, 2010.
[27] C. Ghenai, "Combustion of syngas fuel in gas turbine can combustor," Advances in Mechanical Engineering, vol. 2010, Article ID 342357, 13 pages, 2010.

[28] R. F. Batchelder and C. F. Yuan, Evaluation of Use of Syngas for Coal Liquefaction, Pittsburgh Energy Technology Center, US. Department of Energy, Pittsburgh, Pa, USA.

[29] K.-T. Wu, H. T. Lee, C. I. Juch et al., "Study of syngas co-firing and reburning in a coal fired boiler," Fuel, vol. 83, no. 14-15, pp. 1991-2000, 2004.

[30] P. C. Munasinghe and S. K. Khanal, "Biomass-derived syngas fermentation into biofuels: opportunities and challenges," Bioresource Technology, vol. 101, no. 13, pp. 5013-5022, 2010.

[31] V. Prabu and S. Jayanti, "Underground coal-air gasification based solid oxide fuel cell system," Applied Energy, vol. 94, pp. 406-414, 2012

[32] E. Shoko, B. McLellan, A. L. Dicks, and J. C. D. da Costa, "Hydrogen from coal: production and utilisation technologies," International Journal of Coal Geology, vol. 65, no. 3-4, pp. 213222, 2006.

[33] T. A. Adams II and P. I. Barton, "High-efficiency power production from natural gas with carbon capture," Journal of Power Sources, vol. 195, no. 7, pp. 1971-1983, 2010.

[34] I. Wender, "Reactions of synthesis gas," Fuel Processing Technology, vol. 48, no. 3, pp. 189-297, 1996.

[35] M. A. Rakib, J. R. Grace, C. J. Lim, S. S. E. H. Elnashaie, and B. Ghiasi, "Steam reforming of propane in a fluidized bed membrane reactor for hydrogen production," International Journal of Hydrogen Energy, vol. 35, no. 12, pp. 6276-6290, 2010.

[36] V. R. Choudhary and K. C. Mondal, " $\mathrm{CO}_{2}$ reforming of methane combined with steam reforming or partial oxidation of methane to syngas over $\mathrm{NdCoO}_{3}$ perovskite-type mixed metal-oxide catalyst," Applied Energy, vol. 83, no. 9, pp. 1024-1032, 2006.

[37] L. B. Råberg, M. B. Jensen, U. Olsbye et al., "Propane dry reforming to synthesis gas over Ni-based catalysts: influence of support and operating parameters on catalyst activity and stability," Journal of Catalysis, vol. 249, no. 2, pp. 250-260, 2007.

[38] A. M. O'Connor and J. R. H. Ross, "The effect of $\mathrm{O}_{2}$ addition on the carbon dioxide reforming of methane over $\mathrm{Pt} / \mathrm{ZrO}_{2}$ catalysts," Catalysis Today, vol. 46, no. 2-3, pp. 203-210, 1998.

[39] Y. Yi, A. D. Rao, J. Brouwer, and G. S. Samuelsen, "Fuel flexibility study of an integrated $25 \mathrm{~kW}$ SOFC reformer system," Journal of Power Sources, vol. 144, no. 1, pp. 67-76, 2005.

[40] G. Vourliotakis, G. Skevis, and M. A. Founti, "Combustion chemistry aspects of alternative fuels reforming for hightemperature fuel cell applications," International Journal of Hydrogen Energy, vol. 37, pp. 16649-16662, 2012.

[41] I. Schoegl and J. L. Ellzey, "A mesoscale fuel reformer to produce syngas in portable power systems," Proceedings of the Combustion Institute, vol. 32, pp. 3223-3230, 2009.

[42] D. L. Trimm, "Coke formation and minimisation during steam reforming reactions," Catalysis Today, vol. 37, no. 3, pp. 233-238, 1997.

[43] B. T. Schädel, M. Duisberg, and O. Deutschmann, "Steam reforming of methane, ethane, propane, butane, and natural gas over a rhodium-based catalyst," Catalysis Today, vol. 142, no. 1-2, pp. 42-51, 2009.

[44] B. Purkayastha and P. K. Bansal, "An experimental study on HC290 and a commercial liquefied petroleum gas (LPG) mix as suitable replacements for HCFC22," International Journal of Refrigeration, vol. 21, no. 1, pp. 3-17, 1998. 
[45] HSC Chemistry [software]. Version 5. 1 Pori: Outokumpu Research Oy, 2002.

[46] X. D. Wang, N. Wang, J. Zhao, and L. Wang, "Thermodynamic analysis of propane dry and steam reforming for synthesis gas or hydrogen production," International Journal of Hydrogen Energy, vol. 35, no. 23, pp. 12800-12807, 2010.

[47] S. Liu, Y. Wang, L. Yu, and J. Oakey, "Thermodynamic equilibrium study of trace element transformation during underground coal gasification," Fuel Processing Technology, vol. 87, no. 3, pp. 209-215, 2006.

[48] S. Letellier, F. Marias, P. Cezac, and J. P. Serin, "Gasification of aqueous biomass in supercritical water: a thermodynamic equilibrium analysis," Journal of Supercritical Fluids, vol. 51, no. 3, pp. 353-361, 2010.

[49] A. Haryanto, S. D. Fernando, L. O. Pordesimo, and S. Adhikari, "Upgrading of syngas derived from biomass gasification: a thermodynamic analysis," Biomass and Bioenergy, vol. 33, no. 5, pp. 882-889, 2009.

[50] G. R. Kale and S. S. Sonar, "Combined reforming of chemical looping combustion products: a thermodynamic analysis," Chemical Technology, vol. 6, no. 2, pp. 98-106, 2011.

[51] G. R. Kale and B. D. Kulkarni, "Thermodynamic analysis of dry autothermal reforming of glycerol," Fuel Processing Technology, vol. 91, no. 5, pp. 520-530, 2010.

[52] G. R. Kale, B. D. Kulkarni, and A. R. Joshi, “Thermodynamic study of combining chemical looping combustion and combined reforming of propane," Fuel, vol. 89, no. 10, pp. 3141-3146, 2010.

[53] G. R. Kale and B. D. Kulkarni, "Thermoneutral point analysis of ethanol dry autothermal reforming," Chemical Engineering Journal, vol. 165, no. 3, pp. 864-873, 2010.

[54] G. R. Kale and B. D. Kulkarni, "An alternative process for gasoline fuel processors," International Journal of Hydrogen Energy, vol. 36, no. 3, pp. 2118-2127, 2011.

[55] R. H. Perry and D. W. Green, Chemical Engineers' Handbook, McGraw Hill, 7th edition, 1997. 

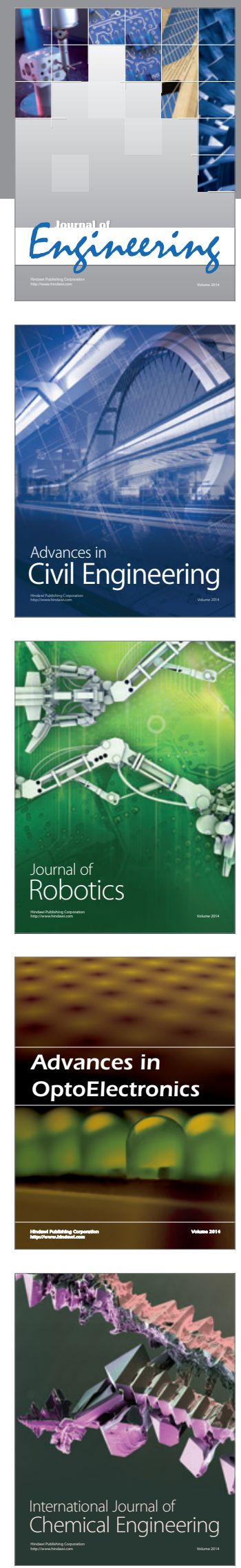

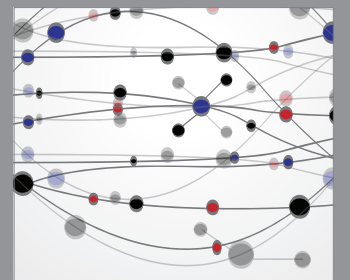

The Scientific World Journal
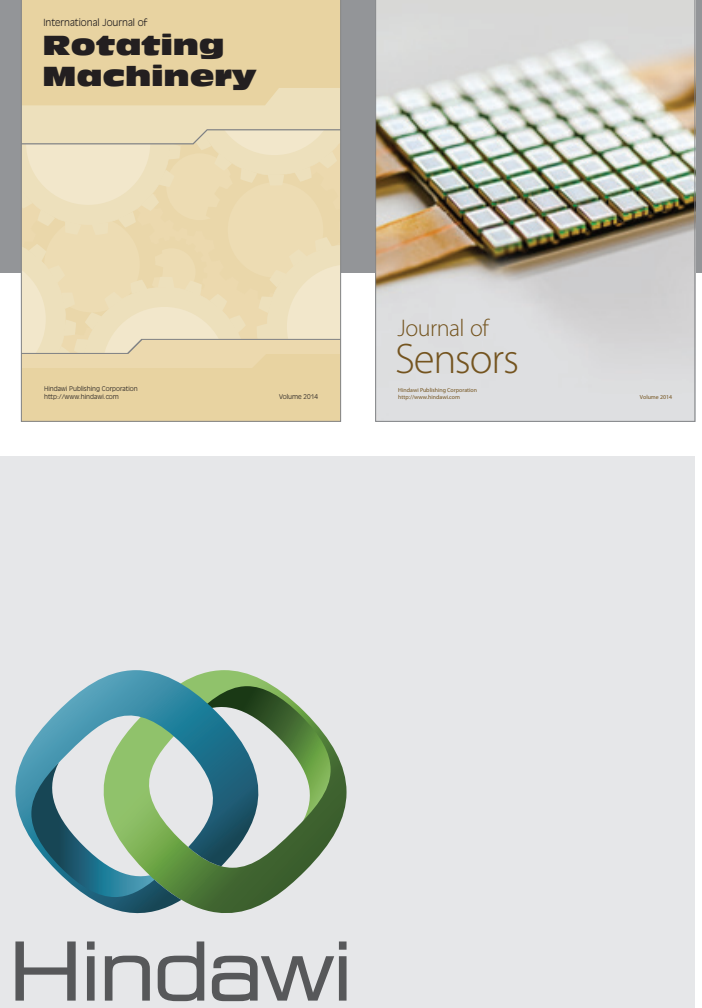

Submit your manuscripts at http://www.hindawi.com
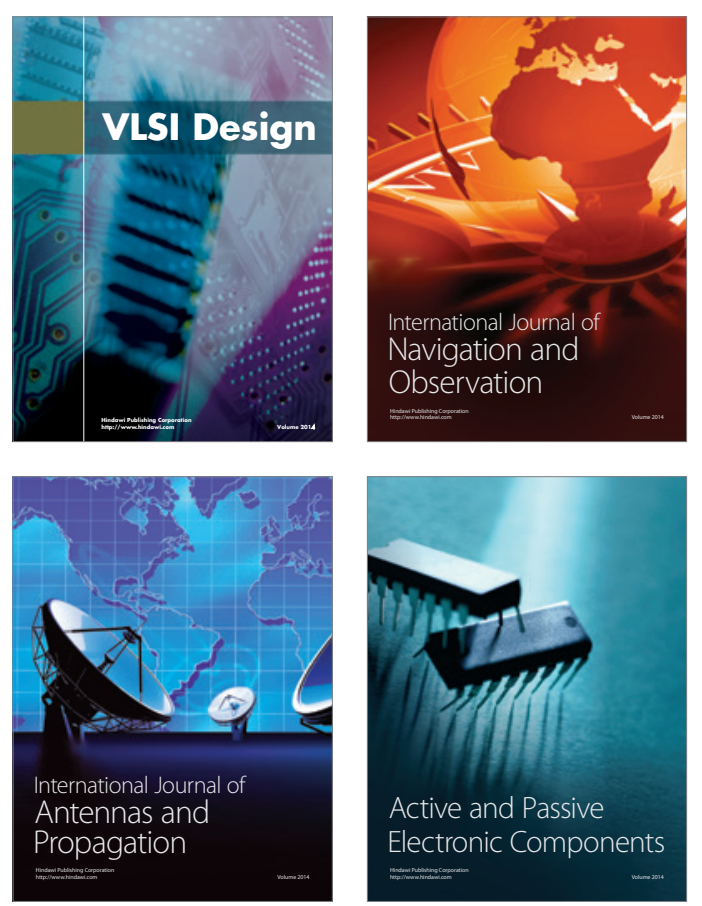
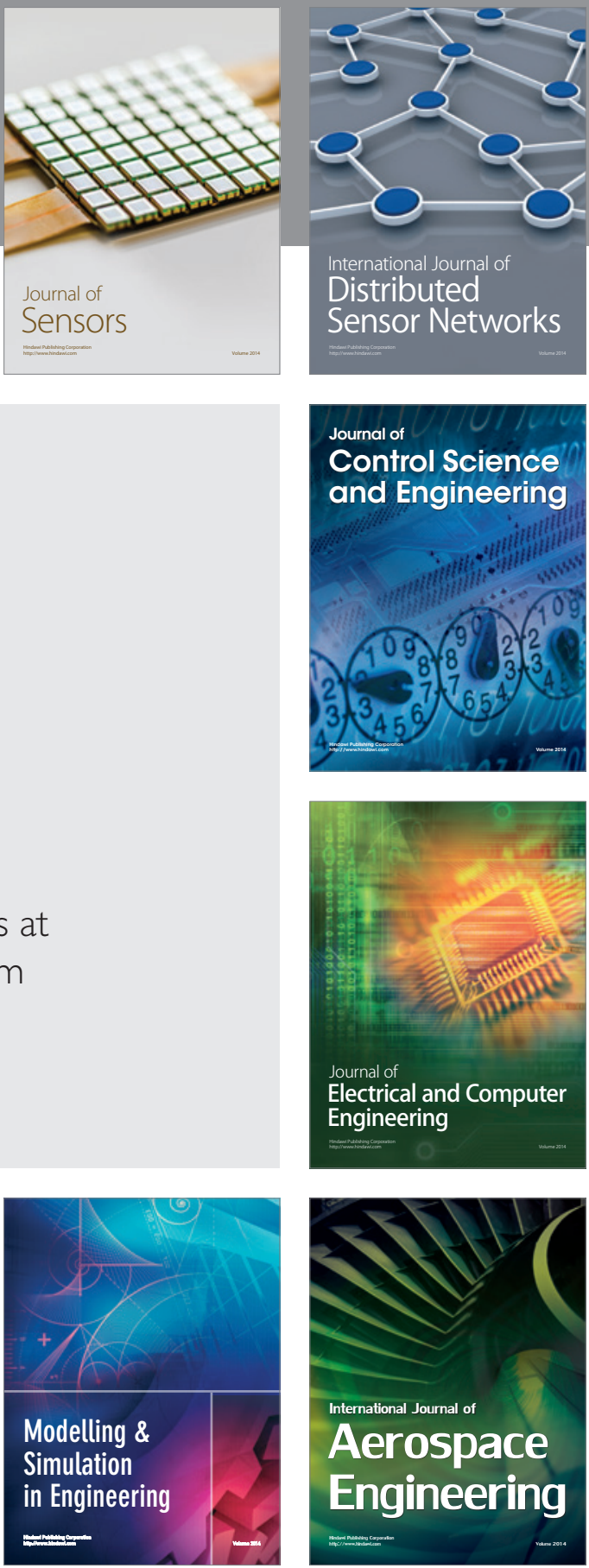

Journal of

Control Science

and Engineering
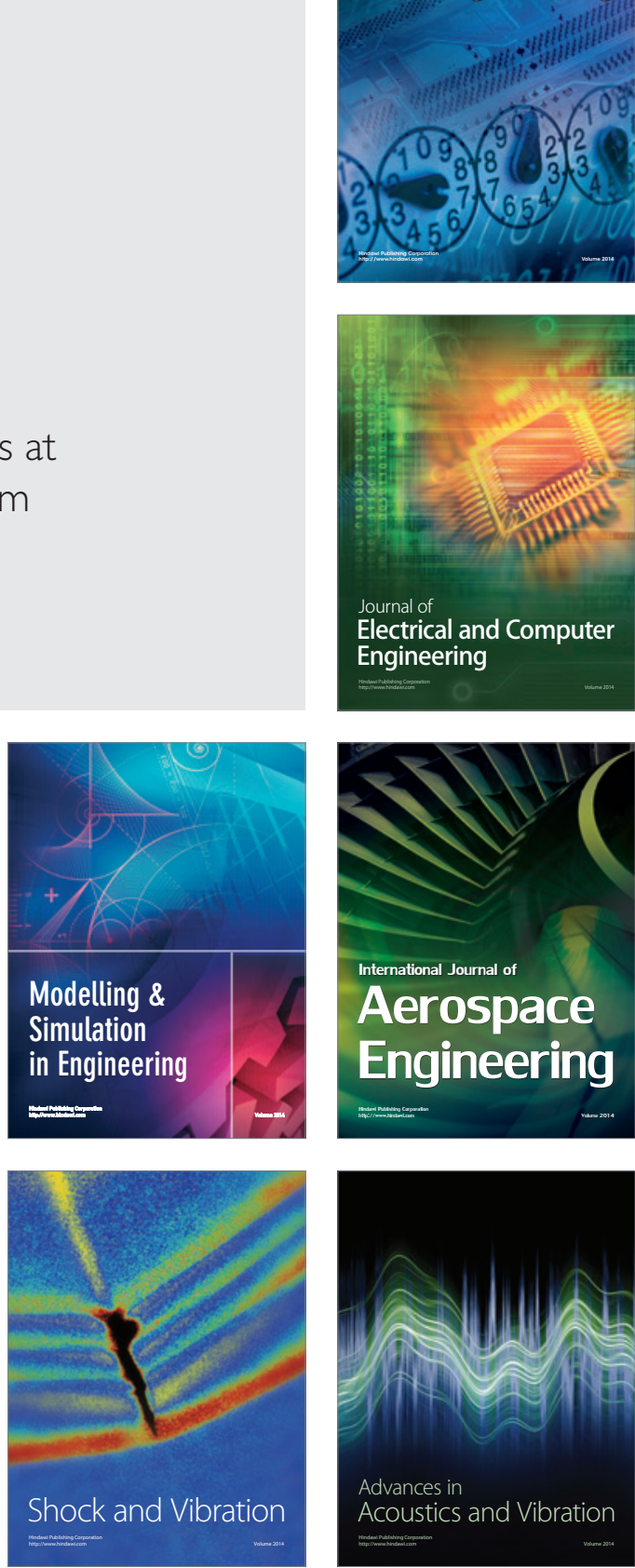